\title{
MOTIVASI MAGANG KERJA MAHASISWA PARIWISATA BALI DI AMERIKA SERIKAT
}

\author{
Putu Eka Wirawan1), I Made Antara2), Dewa Putu Oka Prasiasa ${ }^{3)}$ \\ 1) Sekolah Tinggi Pariwisata Bali International, \\ 2) Universitas Udayana, 3) STIMI Handayani Denpasar
}

\begin{abstract}
Job training program is useful to enrich the extent the theory that is given during the lectures can be applied in the workplace. This research discusses about user perception which is more focused on competence and productivity aspects of students who are following job training and also discuss about extrinsic and intrinsic motivations of Bali tourism students who are following job training in the United States (US) related to several factors such as: knowledge, skill, self-concept/value, personal characteristic and motive. A validity and reliability test of questionnaire has been done. Discussion of factor analysis used is confirmatory factor analysis using SPSS 20.0 for windows. The results showed that the general perception has been well described by the user. Related to perception assessment variable in detail can be described that the variable of the students' ability to complete the task with knowledge got bad score from the user. Students argued that job training in the US would provide excellent benefits in terms of knowledge, skills, self-concept, personal characteristic and motive. Based on the analysis, all variables could explain five factors, which can be factors that motivate students to do job training in the US.
\end{abstract}

Keywords: tourism student motivation, job training, hotel industry

\begin{abstract}
Abstrak
Program magang dijadikan sebagai sarana untuk memperkaya sejauh manakah teori-teori yang diberikan selama perkuliahan dapat diaplikasikan dalam dunia kerja. Penelitian ini membahas persepsi user lebih ditekankan pada aspek kompetensi dan produktivitas mahasiswa yang sedang mengikuti magang dan membahas tentang motivasi ektrinsik dan intrinsik mahasiswa pariwisata Bali magang kerja di Amerika terkait dengan faktor pengetahuan, keterampilan, konsep diri/nilai, karakteristik
\end{abstract}


pribadi dan motif. Dilakukan Uji validitas dan reliabilitas kuisioner. Pada pembahasan analisis faktor yang digunakan adalah analisis faktor konfirmatori (confirmatory factor analysis) menggunakan program SPSS 20.0 for windows. Hasil penelitian menunjukan bahwa nilai persepsi secara umum digambarkan baik oleh user. Terkait dengan variabel penilaian persepsi secara rinci dapat digambarkan bahwa variabel kemampuan mahasiswa untuk menyelesaikan tugas dengan pengetahuan yang dimiliki diberikan nilai buruk oleh user. Mahasiswa berpandangan bahwa kegiatan magang kerja di Amerika akan memberikan manfaat yang sangat baik dalam hal pengetahuan, keterampilan, konsep diri, karakteristik pribadi dan motif. Berdasarkan hasil analisis, seluruh variabel dapat menjelaskan lima faktor yang menjadi faktor motivasi mahasiswa untuk mengikuti magang kerja di Amerika.

Kata kunci : Motivasi mahasiswa pariwisata, magang kerja, industri hotel

\section{Pendahuluan}

Pariwisata adalah salah satu bagian dari fenomena modernisasi, yang tidak dapat dihindari apalagi ditolak kehadirannya. Pariwisata sebagai suatu industri tidak dapat diingkari telah memberikan kontribusi bagi kehidupan masyarakat, terutama dari sisi ekonomi. Pesatnya kemajuan ilmu pengetahuan dan teknologi yang terus berkembang, memerlukan sumber daya manusia berkualitas unggul, termasuk didalamnya sumber daya manusia pariwisata yang diharapkan mau terus menerus mengubah diri agar tetap eksis mengikuti perkembangan yang terjadi. Untuk memenuhi tenaga terampil dan professional dalam bidang pariwisata yang diharapkan, pemerintah telah melakukan perluasan, peningkatan mutu dan relevansi melalui pendidikan tinggi bidang pariwisata. Hal ini diselenggarakan melalui pendidikan formal maupun non formal. Di samping itu untuk memenuhi kebutuhan tenaga kerja dibidang pariwisata sesuai dengan yang diharapkan, pemerintah telah melakukan perluasan, peningkatan mutu dan relevansi melalui pendidikan tinggi bidang pariwisata. Konsep pendidikan ini diterapkan pada jenjang pendidikan kepariwisataan mulai dari Diploma 1, Diploma 2, Diploma 3 dan Diploma 4.

Perkembangan pariwisata yang cukup pesat memberikan dampak yang positif bagi pembangunan sarana serta fasilitas pokok, penunjang dan pelengkap pariwisata. Banyaknya fasilitas tersebut secara langsung membuka peluang bagi ketersediaan peluang kerja. Beragamnya keterse- 
diaan peluang kerja di industri pariwisata, baik dalam skala nasional maupun internasional memberikan kesempatan yang luas bagi mahasiswa pariwisata Bali untuk memilih sektor yang paling cocok dan sesuai menurut mereka. Beberapa pertimbangan digunakan sebagai alat ukur untuk memilih tempat terbaik bagi mereka untuk magang. Lokasi magang kerja mahasiswa di Amerika Serikat berupa Hotel Bintang Lima yang tersebar disejumlah daerah di Amerika Serikat. Sebagai pihak pengguna jasa dan kemampuan dari mahasiswa magang, pandangan dan persepsi user menjadi hal yang penting untuk diperhatikan agar pembekalan kemampuan dan keterampilan yang diberikan kepada mahasiswa dapat sesuai dengan kebutuhan dan permintaan Hotel Bintang Lima atau lokasi magang sebagai user. Dibutuhkan data tentang persepsi user terhadap kompetensi dan produktivitas mahasiswa yang mengikuti magang kerja sebagai tolak ukur keberhasilan proses pendidikan.

Tujuan umum dari penelitian ini adalah untuk mendeskripsikan faktorfaktor yang memotivasi mahasiswa pariwisata Bali mengikuti magang di Amerika Serikat. Tujuan khusus dari penelitian ini adalah sebagai berikut : mendeskripsikan persepsi user terhadap kualitas mahasiswa pariwisata Bali mengikuti magang kerja di Amerika Serikat, mengkaji tingkat motivasi mahasiswa pariwisata Bali mengikuti magang kerja di Amerika Serikat, menganalisis faktor-faktor yang mempengaruhi motivasi mahasiswa pariwisata Bali untuk magang di Amerika Serikat.

\section{Teori dan Metode}

Istilah motivasi berasal dari kata Latin"movere" yang mempunyai arti dorongan atau menggerakkan. Motivasi dapat diartikan sebagai daya penggerak yang menciptakan kegairahan kerja seseorang agar mereka mau bekerja sama, bekerja efektif dan terintegrasi dengan segala daya upayanya untuk mencapai kepuasan (Hasibuan, 2011). Menurut Handoko (dalam Witarsana, 2012), jika dilihat atas dasar fungsinya motivasi terbagi atas motivasi intrinsik dan motivasi ekstrinsik. Motivasi ektrinsik terdiri atas tiga faktor yang mengacu kepada Spencer (dalam Palan, 2007) faktor pengetahuan dan faktor konsep diri/nilai dan SKKNI (Kep. 239/ $\mathrm{MEN} / \mathrm{X} / 2004$ ) yaitu faktor keterampilan.

Faktor Pengetahuan kemudian dijabarkan menjadi sejumlah variabel seperti pendidikan, lingkungan pekerjaan, umur, minat, pengalaman, kebudayaan lingkungan sekitar dan informasi. Faktor keterampilan terdiri atas kemampuan dalam tugas, kemampuan mengelola tugas, kemampuan mengatasi suatu masalah dengan tepat dan kemampuan menyesuaikan dengan lingkungan kerja. Faktor konsep diri terdiri atas variabel konsistensi terhadap aturan kerja, bertindak secara sistematis, kerjasama yang baik, dedikasi yang tinggi dan etos kerja. Penjabaran motivasi intrinsik mengacu 
kepada dua faktor sesuai dengan Spencer (dalam Palan, 2007) yaitu faktor karakteristik pribadi yang terdiri atas karakteristik fisik dan tanggapan terhadap situasi. Sementara faktor motif terdiri atas emosi, hasrat dan kebutuhan psikologis.

Dalam penelitian ini faktor motivasi ektrinsik yang dinilai adalah faktor pengetahuan, faktor keterampilan, dan faktor konsep diri atau nilai - nilai. Penelitian ini meneliti beberapa faktor dari motivasi intrinsik seperti karakteristik pribadi dan motif. Faktor pengetahuan diproksi dengan tujuh variabel yaitu pendidikan, lingkungan pekerjaan, umur, minat, pengalaman, kebudayaan lingkungan sekitar, informasi. Faktor keterampilan diproksi dengan empat variabel yaitu kemampuan dalam tugas, kemampuan mengelola tugas, kemampuan mengatasi suatu masalah dengan tepat, kemampuan menyesuaikan dengan lingkungan kerja.

Faktor konsep diri atau nilai-nilai diproksi dengan lima variabel konsisten terhadap aturan kerja, bertindak secara sistematis, kerjasama yang baik, dedikasi yang tinggi dan etos kerja. Faktor karakteristik pribadi diproksi dengan dua variabel yaitu karakteristik fisik dan konsistensi tanggapan terhadap situasi. Faktor motif diproksi dengan tiga variabel yaitu emosi, hasrat dan kebutuhan psikologis. Menurut Trotter dalam Saifuddin (2004) mendefinisikan bahwa seorang yang berkompeten adalah orang yang dengan keterampilannya mengerjakan pekerjaan dengan mudah, cepat, intuitif dan sangat jarang atau tidak pernah membuat kesalahan. Herzberg (dalam Robbins 2008) menyatakan jika ingin memotivasi karyawan pada pekerjaannya, maka diperlukan penekanan pada hal-hal yang berhubungan dengan pekerjaan itu sendiri atau hasil yang diakibatkan seperti peluang promosi, pengakuan, tanggung jawab, dan pencapaian.

Penelitian dilakukan Desember 2015 sampai dengan Agustus 2016. Pemilihan responden didasarkan atas sejumlah Program Studi yang pernah mendapat penawaran kerja sama pengiriman mahasiswa magang sehingga sejumlah mahasiswa pada program studi tersebut akan menjadi sampel penyebaran kuisioner. Berdasarkan pertimbangan waktu, biaya, dan kebutuhan data yang sesuai dengan alat analisis faktor, jumlah responden dalam penelitian ini ditetapkan sebanyak 133 orang mahasiswa pariwisata Bali.

Skala likert yang digunakan pada penelitian ini terdiri atas dua macam skala yaitu; skala tipe pertama terdiri atas sangat berpengaruh, berpengaruh, cukup berpengaruh, kurang berpengaruh dan sangat kurang berpengaruh. Skala tipe kedua terdiri atas; sangat baik, baik, sedang, rendah, sangat rendah. Sebelum menjabarkan hasil kuesioner, untuk membuktikan bahwa kuisioner yang digunakan telah mampu digunakan sebagai alat ukur variabel penelitian dengan baik digunakan metode validitas. Dengan metode ini diperoleh hasil bahwa $r$ tabel adalah sebesar 0.17 untuk tingkat 
siginifikansi 5\% dan 0.22 untuk tingkat signifikansi 1\%. Berdasarkan hasil uji validitas, diperoleh hasil bahwa seluruh variabel yang digunakan dalam penelitian memiliki nilai validitas lebih besar dari $\mathrm{r}$ tabel 0.17 dan $\mathrm{r}$ tabel o.22 sehingga dinyatakan valid. Penentuan tingkat reabilitas mengacu kepada nilai Cronbach'alpha. Bilamana nilai Cronbach'alpha lebih besar dari 0.7 dikatakan bahwa jawaban dari responden Reliable. Berdasarkan hasil perhitungan diperoleh hasil bahwa nilai reabilitas total dengan Cronbach'alpha adalah 0.915, dapat disimpulkan data yang diperoleh dari hasil kusioner adalah reliabelatau jawaban yang diberikan oleh responden adalah konsisten dan dapat dipercaya.

Data yang digunakan dalam pemecahan masalah yang ada diolah dengan analisis faktor menggunakan program SPSS 20.o for windows. Metode ini digunakan untuk melacak beberapa faktor dari sejumlah indikator yang menentukan motivasi mahasiswa pariwisata Bali mengikuti magang kerja pada industri hotel di Amerika. Pada penelitian ini, pembahasan analisis faktor yang digunakan adalah analisis faktor konfirmatori (confirmatory factor analysis).

\section{Pelaksana Penempatan Magang Kerja}

Penempatan magang kerja mahasiswa pariwisata Bali salah satunya dilakukan oleh PT Bali Duta Mandiri yang telah menandatangani kontrak kerjasama dengan International Trainee Network. International Trainee Network, LLC berlokasi di 3325 Wilshire Blvd., Suite 6oo, Los Angeles, California 90010. Kontrak kerjasama ini menjadi dasar hukum bagi PT Bali Duta Mandiri untuk mengirimkan tenaga kerja ke Amerika.

Berdasarkan laporan tahunan kegiatan magang kerja mahasiswa pariwisata pada PT Bali Duta Mandiri, total tenaga kerja yang telah mengajukan aplikasi magang kerja ke Amerika Serikat dari tahun 2010 hingga 2015 adalah berjumlah 615 orang. Pada tahun 2010 sejumlah 28 orang telah mengajukan aplikasi, tahun 2011 meningkat menjadi 52 orang, tahun 2012 berjumlah 79 orang, tahun 2013 berjumlah 154, tahun 2014 berjumlah 159 orang, dan tahun 2015 berjumlah 143 orang.

\section{Persepsi User}

Rekapitulasi skor persepsi perusahaan tempat magang kerja mahasiswa pariwisata Bali di Amerika Serikat. Skor rata-rata adalah sejumlah 4.09 dengan kategori Baik. Dari empat perusahaan tempat magang kerja mahasiswa pariwisata Bali, Aramark Property memberikan nilai terendah dengan skor 3,48 terhadap faktor kompetensi dan produktivitas mahasiswa, sementara St. Regis Bal Harbour, Miami USA memberikan skor terbesar dibandingkan dengan tiga perusahaan lain dengan skor 4.33. Secara umum rata-rata skor faktor produktivitas lebih tinggi (sebesar 4.11) dibandingkan 
dengan kompetensi mahasiswa (skor sebesar 4.08). Dengan hasil penilaian ini dapat digambarkan bahwa user memandang lebih baik kualitas produktivitas mahasiswa magang dibandingkan kualitas kompetensi mahasiswa mengikuti magang kerja di Amerika Serikat (Tabel 1).

Mengacu kepada empat perusahaan tempat magang kerja mahasiswa pariwisata Bali, secara umum memiliki persepsi yang baik terkait dengan kompetensi dan produktivitas. Di antara empat perusahaan tempat magang kerja secara umum Aramark Property memiliki skor persepsi yang cenderung lebih kecil dibandingkan dengan perusahaan yang lain. Aramark Property memiliki persepsi yang baik sementara tiga perusahaan lainnya (The Setai South Beach, St. Regis Bal Harbour, The Setai South Beach) memiliki persepsi yang sangat baik terhadap mahasiswa pariwisata Bali yang mengikuti magang kerja. Penilaian Aramark Property cenderung lebih kecil terkait dengan kompetensi yang dimiliki mahasiswa magang kerja. Kondisi ini dipengaruhi oleh pandangan Aramark Property bahwa mahasiswa yang mengikuti magang kerja kurang memiliki pengetahuan tentang standar kerja perusahaan baik standar volume kerja, standar pelayanan dan standar mutu kerja.

Tabel 1. Persepsi User terhadap Mahasiswa Pariwisata Bali Magang Kerja di Amerika Serikat

\begin{tabular}{|c|c|c|c|c|c|}
\hline \multirow{2}{*}{ No } & \multirow{2}{*}{$\begin{array}{l}\text { Perusahaan Tempat } \\
\text { Magang Kerja }\end{array}$} & \multicolumn{2}{|c|}{$\begin{array}{c}\text { Skor Persepsi Perusahaan } \\
\text { Tempat Magang Kerja } \\
\end{array}$} & \multirow{2}{*}{$\begin{array}{l}\text { Rata-rata } \\
\text { skor } \\
\text { persepsi }\end{array}$} & \multirow{2}{*}{ Kategori } \\
\hline & & Kompetensi & $\begin{array}{l}\text { Produkti- } \\
\text { vitas }\end{array}$ & & \\
\hline 1 & Aramark Property & 3.4 & 3.56 & 3.48 & Baik \\
\hline 2 & $\begin{array}{l}\text { The Setai South Beach, } \\
\text { Miami USA }\end{array}$ & 4.4 & 4.22 & $4 \cdot 31$ & Sangat Baik \\
\hline 3 & $\begin{array}{l}\text { St. Regis Bal Harbour, } \\
\text { Miami USA }\end{array}$ & 4.1 & 4.56 & 4.33 & Sangat Baik \\
\hline 4 & $\begin{array}{l}\text { The Setai South Beach, } \\
\text { Miami USA }\end{array}$ & $4 \cdot 3$ & 4.11 & 4.20 & Sangat Baik \\
\hline & Rata - rata & 4.08 & 4.11 & 4.09 & Baik \\
\hline
\end{tabular}

Sumber : Rekapitulasi Kuisioner, Desember 2015

Terkait dengan sikap mahasiswa magang, umumnya dipandang sangat positif. Sejumlah istilah yang digambarkan oleh user seperti humble, respectfull menjadi ungkapan dari user. Secara umum user sangat puas dengan sikap yang ditunjukan oleh mahasiswa magang. Sejumlah variabel produktifitas mahasiswa yang dinyatakan kurang dibandingkan dengan variabel lain yaitu kemampuan mahasiwa untuk bekerja sesuai dengan target perusahaan, kemampuan mahasiswa untuk bekerja sesuai dengan standar perusahaan, dan kemampuan mahasiswa untuk menerapkan norma 
yang berlaku di perusahaan. Disamping keunggulan dari mahasiswa yang telah melakukan magang, secara umum kekurangan mahasiswa yang telah melakukan magang adalah kemampuan bahasa inggris yang kurang.

\section{Tingkat Motivasi Mahasiswa Magang Kerja di Amerika}

Penentuan tingkat motivasi umum dilakukan dengan menjumlahkan seluruh nilai yang diberikan oleh setiap responden. Setelah itu dibagi dengan jumlah responden sehingga diperoleh rata-rata nilai responden untuk setiap faktor. Rata-rata nilai yang diperoleh berkisar antara 1 sampai dengan 5. Berdasarkan rekapan skor setiap faktor motivasi mahasiswa untuk melakukan magang kerja, diperoleh hasil bahwa faktor karakteristik pribadi merupakan faktor motivasi terbesar dan faktor konsep diri merupakan faktor terkecil. Secara berurutan, rata-rata nilai tiap faktor motivasi mulai dari faktor tertinggi yaitu faktor konsep diri sebesar 4.40, faktor karakteristik pribadi, faktor pengetahuan, faktor keterampilan dan faktor motif dengan nilai yang sama sebesar 4.35 (Tabel 2).

Tabel 2. Motivasi Mahasiswa Pariwisata Bali Magang Kerja di Amerika Serikat

\begin{tabular}{lcccccccc}
\hline \multirow{2}{*}{ Faktor } & \multicolumn{9}{c}{ Motivasi Mahasiswa Pariwisata Bali } & \multicolumn{2}{c}{ Total } & Rata rata & \multirow{2}{*}{ Kategori } \\
\cline { 2 - 6 } & 1 & 2 & 3 & 4 & 5 & Skor & Nilai & \\
\hline Pengetahuan & 5 & 5 & 115 & 332 & 474 & 4058 & 4.35 & Sangat Baik \\
Keterampilan & 0 & 2 & 120 & 397 & 412 & 4012 & 4.35 & Sangat Baik \\
$\begin{array}{l}\text { Konsep Diri / } \\
\text { Nilai }\end{array}$ & 2 & 4 & 46 & 207 & 273 & 2341 & 4.40 & Sangat Baik \\
$\begin{array}{l}\text { Karakteristik } \\
\text { Pribadi }\end{array}$ & $\mathrm{O}$ & 1 & 30 & 107 & 128 & 1160 & 4.36 & Sangat Baik \\
Motif & $\mathrm{O}$ & 1 & 36 & 183 & 179 & 1737 & 4.35 & Sangat Baik \\
\hline Total & 7 & 13 & 347 & 1226 & 1466 & 13308 & 4.36 & Sangat Baik \\
\hline
\end{tabular}

Sumber : Hasil Kuisioner Desember 2015

Berdasarkan hasil kuisioner, diantara 7 variabel motivasi faktor pengetahuan diperoleh hasil bahwa variabel pembentukan karakter yang positif dipersepsikan paling kecil dibandingkan dengan variabel lainnya. Variabel pengalaman terhadap peningkatan keterampilan menjadi variabel yang dipersepsikan tertinggi oleh responden (skor 4.71-Kategori Sangat Tinggi). Peningkatan keterampilan mahasiwa yang dirasakan dengan mengikuti kegiatan magang dominan dinyatakan sangat baik oleh responden. Penggambaran yang tidak memiliki perbedaan yang besar, antara responden dipengaruhi oleh persepsi positif yang terbentuk oleh mahasiswa bahwa magang di Amerika dapat memberikan pengalaman kerja yang berbeda dan lebih baik sehingga pengalaman mahasiswa dapat meningkat.

Penggambaran motivasi faktor keterampilan digambarkan oleh responden dengan interval nilai variabel antara 4.25 (Sangat Baik) sampai dengan 4.49 (Sangat Baik) dengan skala 5. Nilai variabel terendah adalah pengaruh 
kegiatan magang kerja terhadap peningkatan kemampuan mengelola tugas dengan skor 4.25 (Sangat Baik) dan variabel manfaat untuk mengerjakan berbagai tugas dengan skor 4.49 dengan kategori Sangat Baik. Mahasiswa umumnya menganggap bahwa secara umum konsep diri merupakan hal sangat penting, bahkan lebih penting dibandingkan dengan faktor lain. Skor motivasi faktor konsep diri memiliki nilai interval 4.45 (Sangat Baik) sampai dengan 4.33 (Sangat Baik) dengan skala 5. Penggambaran motivasi faktor konsep diri dengan skor terendah yaitu variabel peningkatan kemampuan menerapkan prinsip dan nilai perusahaan dengan skor 4.33 (Sangat Baik). Sementara skor tertinggi terkait dengan variabel peningkatan kemampuan bertindak sistematis dengan skor 4.45 (atau kategori Sangat Baik dalam skala Likert.

Skor variabel terkait dengan persepsi motivasi faktor karakteristik pribadi digambarkan dengan variabel yaitu kualitas fisik dengan skor 4.29 (Sangat Baik) dan variabel kemampuan menghadapi situasi kerja dengan skor 4.43 (Sangat Baik). Kondisi kecerdasan dan kemampuan mahasiswa dalam menghadapi situasi kerja nantinya, dirasakan sangat baik oleh responden. Mahasiswa sangat merasakan bahwa kegiatan magang dapat melatih kecerdasan dalam menghadapi situasi kerja menjadi lebih baik. Skor motivasi faktor konsep diri digambarkan dengan tiga variabel yaitu variabel kemampuan ekspresi emosi dengan skor 4.26 (Sangat Baik), variabel pengembangan kompetensi diri dengan skor 4.44 (Sangat Baik) dan variabel peningkatan kebutuhan psikologis dengan skor 4.36 (Sangat Baik). Berdasarkan kondisi ini, persepsi variabel pengembangan kompetensi diri dipersepsikan lebih besar dibandingkan kemampuan ekspresi emosi dan peningkatan kebutuhan psikologis.

\section{Faktor-faktor yang Berpengaruh terhadap Motivasi}

Berdasarkan hasil analisis faktor terhadap faktor yang berpengaruh terhadap motivasi mahasiswa mengikuti magang kerja diperoleh hasil bahwa secara umum mendukung atau sesuai dengan hipotesis bahwa keseluruhan faktor (faktor pengetahuan, faktor keterampilan, faktor konsep diri, faktor karakteristik pribadi, faktor motif) berpengaruh terhadap motivasi mahasiswa mengikuti magang kerja di Amerika Serikat. Analisis motivasi faktor pengetahuan dilakukan dengan memiliki 7 variabel dasar dari motivasi faktor pengetahuan. Berdasarkan hasil perhitungan total variance explained diperoleh hasil bahwa terdapat 2 faktor yang mampu menjelaskan variabel sebesar 55.584\%. Faktor 1 mampu menjelaskan seluruh variabel sebesar $39.821 \%$ dan faktor dua mampu menjelaskan seluruh variabel sebesar 15.763\%. Faktor 1 terdiri atas variabel kualitas kehidupan (X1.2), pengaruh bimbingan (X1.1), minat mahasiswa magang (X1.4), dan akibat perubahan (X1.3). Faktor 2 terdiri atas variabel pembentukan karakter (X1.7), kualitas 


\section{dan kuantitas (X1.5), dan memberi pengalaman (X1.6). Pembagian faktor ini dengan menggunakan metode rotasi Oblimin Kaiser Normalization (Tabel} $3)$.

\section{Tabel 3. Hasil Statistik Motivasi Faktor Pengetahuan Mahasiswa Pariwisata Bali Magang Kerja di Amerika Serikat}

1. Hasil Test KMO and Bartlett's Test Motivasi Faktor Pengetahuan Mahasiswa Pariwisata Bali Magang Kerja di Amerika Serikat => kebenaran pembentuk faktor

Kaiser-Meyer-Olkin Measure of Sampling Adequacy.

Bartlett's Test of Sphericity

$\begin{array}{lr}\text { Approx. Chi-Square } & 185.468 \\ \text { Df } & 21 \\ \text { Sig. } & .000\end{array}$

2. Matrix Korelasi antar variabel pembentuk motivasi Faktor Pengetahuan Mahasiswa Pariwisata Bali Magang Kerja di Amerika Serikat => korelasi faktor dengan anti image

\begin{tabular}{clccccccc}
\hline & & $\mathrm{X} 1.1$ & $\mathrm{X} 1.2$ & $\mathrm{X} 1.3$ & $\mathrm{X} 1.4$ & $\mathrm{X} 1.5$ & $\mathrm{X} 1.6$ & $\mathrm{X} 1.7$ \\
\hline \multirow{5}{*}{ Pengaruh Bimbingan (X1.1) } & .698 & -.512 & .001 & -.144 & -.105 & .126 & -.100 \\
Knti-image & Kwalitas kehidupan (X1.2) & -.512 & 0.705 & -.271 & -.096 & -.072 & -.081 & .022 \\
Covariance & Mkibat perubahan (X1.3) & .001 & -.271 & .821 & -.166 & -.068 & -.109 & -.126 \\
& Minat mahasiswa magang (X1.4) & -.144 & -.096 & -.166 & .862 & -.028 & -.041 & -.154 \\
& Kualitas dan kuantitas (X1.5) & -.100 & .022 & -.126 & -.154 & -.299 & -.183 & .773 \\
& Memberi pengalaman (X1.6) & -.105 & -.072 & -.068 & -.028 & .811 & -.090 & -.299 \\
& Pembentukan karakter (X1.7) & .126 & -.081 & -.109 & -.041 & -.090 & .737 & -.183 \\
\hline \multirow{5}{*}{$\begin{array}{c}\text { Anti-image } \\
\text { Corelation }\end{array}$} & Pengaruh Bimbingan (X1.1) & .588 & -.291 & .001 & -.098 & -.071 & .091 & -.065 \\
& Kwalitas kehidupan (X1.2) & -.291 & .547 & -.171 & -.063 & -.047 & -.056 & .014 \\
& Minat perubahan (X1.3) & .001 & -.171 & .731 & -.123 & -.051 & -.087 & -.092 \\
& Kualitas dan kuantitas (X1.5) & -.065 & .014 & -.092 & -.116 & -.223 & -.146 & .724 \\
& Memberi pengalaman (X1.6) & -.071 & -.047 & -.051 & -.022 & .770 & -.074 & -.223 \\
& Pembentukan karakter (X1.7) & .091 & -.056 & -.087 & -.034 & -.074 & .882 & -.146 \\
\hline
\end{tabular}

3. Komunalitas Motivasi faktor Pengetahuan Mahasiswa Pariwisata Bali Magang Kerja di Amerika Serikat => pengaruh (\%) setiap variabel terhadap Motivasi Mengikuti Magang

\begin{tabular}{lcc}
\hline & Initial & Exstraction \\
\hline Pengaruh Bimbingan (X1.1) & 1.000 & 0.715076 \\
Kwalitas kehidupan (X1.2) & 1.000 & 0.702482 \\
Akibat perubahan (X1.3) & 1.000 & 0.442992 \\
Minat mahasiswa magang (X1.4) & 1.000 & 0.399453 \\
Kualitas dan kuantitas (X1.5) & 1.000 & 0.446668 \\
Memberi pengalaman (X1.6) & 1.000 & 0.618502 \\
Pembentukan karakter (X1.7) & 1.000 & 0.565730 \\
\hline
\end{tabular}

4. Nilai Eigenvalue, Persentase Varians dan Presentase Komulatif Varians dari tujuh variabel Pembentuk Motivasi faktor Pengetahuan Mahasiswa Pariwisata Bali Magang Kerja di Amerika Serikat => Kontribusi faktor pembentuk persepsi (\%) dan tingkat signifikansi akar ciri (eigenvalue)

\begin{tabular}{crrrrrr}
\hline Componen & \multicolumn{3}{c}{ Initial Eigenvalues } & \multicolumn{2}{c}{ Extraction Sums of Squared Loadings } \\
\cline { 2 - 6 } & \multicolumn{1}{c}{ Total } & \% of Variance & Cumulative \% & Total & \% of Variance & Cumulative \% \\
\hline 1 & 2.787 & 39.821 & 39.821 & 2.787 & 39.821 & 39.821 \\
2 & 1.103 & 15.763 & 55.584 & 1.103 & 15.763 & 55.584 \\
3 & .816 & 11.654 & 67.238 & & & \\
4 & .729 & 10.421 & 77.659 & & & \\
5 & .648 & 9.253 & 86.912 & & \\
6 & .558 & 7.966 & 94.878 & & & \\
7 & .359 & 5.122 & 100.000 & & & \\
\hline
\end{tabular}


5. Matrik Motivasi faktor Pengetahuan Mahasiswa Mahasiswa Pariwisata Bali Magang Kerja di Amerika Serikat dengan rotasi Oblimin with Kaiser Normalization => Korelasi setiap variabel terhadap faktor terbentuk

\begin{tabular}{lcc}
\hline \multicolumn{1}{c}{ Variabel } & \multicolumn{2}{c}{ Componen } \\
\cline { 2 - 3 } & Pengetahuan Eksternal (1) & Pengetahuan Internal (2) \\
\hline Pengaruh Bimbingan (X1.1) & .837 & .234 \\
Kwalitas kehidupan (X1.2) & .831 & .127 \\
Akibat perubahan (X1.3) & .608 & .362 \\
Minat mahasiswa magang (X1.4) & .605 & .460 \\
Kualitas dan kuantitas (X1.5) & .065 & .761 \\
Memberi pengalaman (X1.6) & .416 & .729 \\
Pembentukan karakter (X1.7) & .435 & .622 \\
\hline
\end{tabular}

Keterangan :

Nilai komunalitas < 0.500 sehingga disimpulkan tidak dapat mendeskripsikan faktor

Sumber : Hasil Analisis SPSS

Analisis motivasi faktor keterampilan dilakukan dengan memiliki 5 variabel dasar dari motivasi faktor keterampilan yaitu : manfaat untuk mengerjakan berbagai tugas, peningkatan kemampuan mengelola tugas, peningkatan kemampuan mengatasi masalah, peningkatan kemampuan berkembang dan beradaptasi, peningkatan kemampuan menyesuaikan diri dengan lingkungan kerja. Berdasarkan hasil perhitungan diperoleh hasil bahwa seluruh variabel memiliki nilai diatas 0.500 sehingga dapat dikatakan bahwa kelima variabel dinyatakan dapat menjelaskan Faktor keterampilan terkait dengan pembentukan motivasi melakukan kegiatan magang kerja di Amerika (Tabel 4).

Tabel 4. Hasil Statistik Motivasi Faktor Keterampilan Mahasiswa Pariwisata Bali Magang Kerja di Amerika Serikat

1. Hasil Test KMO and Bartlett's Test Motivasi Faktor Keterampilan Mahasiswa Pariwisata Bali Magang Kerja di Amerika Serikat => kebenaran pembentuk faktor

\begin{tabular}{lrr}
\hline Kaiser-Meyer-Olkin Measure of Sampling Adequacy. & & .807 \\
Bartlett's Test of Sphericity & Approx. Chi-Square & 191.881 \\
& Df & 10 \\
& Sig & .000 \\
\hline
\end{tabular}

2. Matrix Korelasi antar variabel pembentuk motivasi Faktor Keterampilan Mahasiswa Pariwisata Bali Magang Kerja di Amerika Serikat => korelasi faktor dengan anti image

\begin{tabular}{rlrrrrr} 
& & $\mathrm{X} 2.1$ & $\mathrm{X} 2.2$ & $\mathrm{X} 2.3$ & $\mathrm{X} 2.4$ & $\mathrm{X} 2.5$ \\
\hline $\begin{array}{l}\text { Anti-image } \\
\text { Covariance }\end{array}$ & Manfaat positif (X2.1) & .592 & -.029 & -.087 & -.185 & -.209 \\
& kemampuan dalam mengelola (X2.2) & -.029 & .634 & -.206 & -.140 & -.109 \\
& kemampuan dalam menghadapi masalah (X2.3) & -.087 & -.206 & .610 & -.021 & -.155 \\
& Adaptasi dengan lingkungan sekitar (X2.4) & -.185 & -.140 & -.021 & .724 & -.047 \\
& Peningkatan kemampuan (X2.5) & -.209 & -.109 & -.155 & -.047 & .563 \\
\hline \multirow{2}{*}{$\begin{array}{l}\text { Anti-image } \\
\text { Corelation }\end{array}$} & Manfaat positif (X2.1) & .792 & -.048 & -.145 & -.282 & -.361 \\
& kemampuan dalam mengelola (X2.2) & -.048 & .813 & -.332 & -.206 & -.182 \\
& kemampuan dalam menghadapi masalah (X2.3) & -.145 & -.332 & .809 & -.031 & -.264 \\
& Adaptasi dengan lingkungan sekitar (X2.4) & -.282 & -.206 & -.031 & .831 & -.073
\end{tabular}


Peningkatan kemampuan (X2.5)

$-.361$

$-.182$

$-.264$

$-.073 \quad .800$

3. Komunalitas motivasi faktor Keterampilan Mahasiswa Pariwisata Bali Magang Kerja di Amerika Serikat => pengaruh (\%) setiap variabel terhadap Motivasi Mengikuti Magang

\begin{tabular}{llc}
\hline & Initial & Exstraction \\
\hline Manfaat positif (X2.1) & 1.000 & .593 \\
kemampuan dalam mengelola (X2.2) & 1.000 & .557 \\
kemampuan dalam menghadapi masalah (X2.3) & 1.000 & .577 \\
Adaptasi dengan lingkungan sekitar (X2.4) & 1.000 & .448 \\
Peningkatan kemampuan (X2.5) & 1.000 & .632 \\
\hline
\end{tabular}

4. Nilai Eigenvalue, Persentase Varians dan Presentase Komulatif Varians dari tujuh variabel Pembentuk Motivasi faktor Keterampilan Mahasiswa Pariwisata Bali Magang Kerja di Amerika Serikat $=>$ Kontribusi faktor pembentuk persepsi (\%) dan tingkat signifikansi akar ciri (eigenvalue)

\begin{tabular}{ccccccc}
\hline \multirow{2}{*}{ Componen } & \multicolumn{3}{c}{ Initial Eigenvalues } & \multicolumn{2}{c}{ Extraction Sums of Squared Loadings } \\
\cline { 2 - 6 } & Total & $\begin{array}{c}\text { \% of Vari- } \\
\text { ance }\end{array}$ & $\begin{array}{c}\text { Cumulative } \\
\%\end{array}$ & Total & $\begin{array}{c}\text { \% of Vari- } \\
\text { ance }\end{array}$ & $\begin{array}{c}\text { Cumulative } \\
\%\end{array}$ \\
\hline 1 & 2.807 & 56.146 & 56.146 & 2.807 & 56.146 & 56.146 \\
2 & .719 & 14.382 & 70.528 & & \\
3 & .621 & 12.424 & 82.952 & & \\
4 & .447 & 8.940 & 91.892 & & \\
5 & .405 & 8.108 & 100.000 & & \\
\hline
\end{tabular}

5. Matrik Motivasi faktor Keterampilan Mahasiswa Pariwisata Bali Magang Kerja di Amerika Serikat dengan rotasi Oblimin with Kaiser Normalization $=>$ Korelasi setiap variabel terhadap faktor terbentuk

\begin{tabular}{lc}
\hline \multicolumn{1}{c}{ Variabel } & $\begin{array}{c}\text { Componen } \\
\text { Faktor Keterampilan (1) }\end{array}$ \\
\hline Manfaat positif (X2.1) & .795 \\
kemampuan dalam mengelola (X2.2) & .770 \\
kemampuan dalam menghadapi masalah (X2.3) & .759 \\
Adaptasi dengan lingkungan sekitar (X2.4) & .746 \\
Peningkatan kemampuan (X2.5) & .670 \\
\hline
\end{tabular}

Sumber : Hasil Analisis SPSS

Analisis komunalitas faktor konsep diri diperoleh hasil bahwa peningkatan kemampuan menerapkan prinsip dan nilai perusahaan memiliki nilai ekstraksi 0.596, peningkatan kemampuan bertindak sistematis memiliki nilai ekstraksi 0.634 , kemampuan kerjasama tim memiliki nilai ekstraksi o.670. Sementara faktor dan tingkat ketaatan dan kesetiaan memiliki nilai ekstraksi 0.452 dapat disimpulkan tidak dapat menjelaskan terkait dengan faktor konsep diri. Bila dilihat dari hasil perhitungan total variance explained diperoleh hasil bahwa terdapat 1 faktor yang mampu menjelaskan variabel sebesar 58.799\% (Tabel 5).

Analisis komunalitas faktor karakteristik pribadi diperoleh hasil bahwa kwalitas fisik dan kemampuan menghadapi situasi kerja memiliki nilai komunalitas 0.550. Dengan nilai ekstraksi diatas 0.500 dapat disimpulkan bahwa kedua faktor tersebut dikatakan dapat menjelaskan faktor sebesar $55 \%$. Bila dilihat dari hasil perhitungan total variance explained diperoleh hasil bahwa terdapat 1 faktor yang mampu menjelaskan variabel sebesar 54.996\% (Tabel 6). 
Tabel 5. Hasil Statistik Motivasi Faktor Konsep Diri Mahasiswa Pariwisata Bali Magang Kerja di Amerika Serikat

1. Hasil Test KMO and Bartlett's Test Motivasi Faktor Konsep Diri Mahasiswa Pariwisata Bali Magang Kerja di Amerika Serikat => kebenaran pembentuk faktor

Kaiser-Meyer-Olkin Measure of Sampling Adequacy.

Bartlett's Test of Sphericity

$\begin{array}{lr}\text { Approx. Chi-Square } & 129.759 \\ \text { Df } & 6 \\ \text {.Sig } & 000\end{array}$

2. Matrix Korelasi antar variabel pembentuk motivasi Faktor Konsep Diri Mahasiswa Pariwisata Bali Magang Kerja di Amerika Serikat => korelasi faktor dengan anti image

\begin{tabular}{llcccc}
\hline & & $\mathrm{X}_{3.1}$ & $\mathrm{X}_{3.2}$ & $\mathrm{X}_{3.3}$ & $\mathrm{X}_{3.4}$ \\
\hline \multirow{2}{*}{$\begin{array}{l}\text { Anti-image } \\
\text { Covariance }\end{array}$} & Peningkatan menerapakan yang di miliki oleh & .657 & -.210 & -.169 & -.065 \\
& Kemampuan bertindak sismatis (X3.2) & -.210 & .624 & -.192 & -.087 \\
& Kualitas kerja tim (X3.3) & -.169 & -.192 & .598 & -.192 \\
& Tingkat ketaatan (X3.4) & -.065 & -.087 & -.192 & .773 \\
\hline \multirow{2}{*}{$\begin{array}{l}\text { Anti-image } \\
\text { Corelation }\end{array}$} & Peningkatan menerapakan yang di miliki oleh & .768 & -.328 & -.270 & -.091 \\
& Kerusahaaan (X3.1) & -.328 & .754 & -.314 & -.126 \\
& Kualitas kerja tim (X3.3) & -.270 & -.314 & .744 & -.282 \\
& Tingkat ketaatan (X3.4) & -.091 & -.126 & -.282 & .809 \\
\hline
\end{tabular}

3. Komunalitas variabel faktor Konsep Diri Mahasiswa Pariwisata Bali Magang Kerja di Amerika Serikat => pengaruh (\%) setiap variabel terhadap Motivasi Mengikuti Magang

\begin{tabular}{llc}
\hline & Initial & Exstraction \\
\hline Peningkatan menerapakan yang di miliki oleh perusahaaan $\left(\mathrm{X}_{3} .1\right)$ & 1.000 & .596 \\
Kemampuan bertindak sismatis $\left(\mathrm{X}_{3} .2\right)$ & 1.000 & .634 \\
Kualitas kerja tim (X3.3) & 1.000 & .670 \\
Tingkat ketaatan (X3.4) & 1.000 & .452 \\
\hline
\end{tabular}

4. Nilai Eigenvalue, Persentase Varians dan Presentase Komulatif Varians dari tujuh variabel Pembentuk Motivasi faktor Konsep Diri Mahasiswa Pariwisata Bali Magang Kerja di Amerika Serikat => Kontribusi faktor pembentuk persepsi (\%) dan tingkat signifikansi akar ciri (eigenvalue)

\begin{tabular}{ccccccc}
\hline \multirow{2}{*}{ Componen } & \multicolumn{3}{c}{ Initial Eigenvalues } & \multicolumn{2}{c}{ Extraction Sums of Squared Loadings } \\
\cline { 2 - 6 } & Total & \% of Variance & Cumulative \% & Total & \% of Variance & Cumulative \% \\
\hline 1 & 2.352 & 58.799 & 58.799 & 2.352 & 58.799 & 58.799 \\
2 & .706 & 17.640 & 76.438 & & & \\
3 & .487 & 12.178 & 88.617 & & & \\
4 & .455 & 11.383 & 100.000 & & & \\
\hline
\end{tabular}

5. Matrik Motivasi faktor Konsep Diri Mahasiswa Pariwisata Bali Magang Kerja di Amerika Serikat dengan rotasi Oblimin with Kaiser Normalization $=>$ Korelasi setiap variabel terhadap faktor terbentuk

\section{Variabel}

Peningkatan menerapakan yang di miliki oleh perusahaaan $\left(\mathrm{X}_{3.1}\right)$

Kemampuan bertindak sismatis ( $\left.\mathrm{X}_{3} .2\right)$

Kualitas kerja tim ( $\left.\mathrm{X}_{3.3}\right)$

Tingkat ketaatan (X3.4)

Sumber : Hasil Analisis SPSS
Componen

Faktor Konsep Diri (1) 
Tabel 6. Hasil Statistik Motivasi Faktor Karakteristik Pribadi Mahasiswa Pariwisata Bali Magang Kerja di Amerika Serikat

1. Hasil Test KMO and Bartlett's Test Motivasi Faktor Karakteristik Pribadi Mahasiswa Pariwisata Bali Magang Kerja di Amerika Serikat => kebenaran pembentuk faktor

\begin{tabular}{llr}
\hline Kaiser-Meyer-Olkin Measure of Sampling Adequacy. & & .500 \\
Bartlett's Test of Sphericity & Approx. Chi-Square & 1.309 \\
& Df & 1 \\
& Sig & .252 \\
\hline
\end{tabular}

2. Matrix Korelasi antar variabel pembentuk motivasi Faktor Karakteristik Pribadi Mahasiswa Pariwisata Bali Magang Kerja di Amerika Serikat => korelasi faktor dengan anti image

\begin{tabular}{llcc}
\hline & & X4.1 & X4.2 \\
\hline Anti-image & Peningkatan stamina (X4.1) & .990 & -.099 \\
Covariance & Kecerdasan dan kemampuan mnghadapi situasi kerja (X4.2) & -.099 & .990 \\
\hline Anti-image & Peningkatan stamina (X4.1) & .500 & -.100 \\
Corelation & Kecerdasan dan kemampuan mnghadapi situasi kerja (X4.2) & -.100 & 500 \\
\hline
\end{tabular}

3. Komunalitas variabel faktor Karakteristik Pribadi Mahasiswa Pariwisata Bali Magang Kerja di Amerika Serikat $=>$ pengaruh (\%) setiap variabel terhadap Motivasi Mengikuti Magang

\begin{tabular}{cc} 
Initial & Exstraction \\
1.000 & .550 \\
1.000 & .550 \\
\hline
\end{tabular}

Peningkatan stamina (X4.1)
Kecerdasan dan kemampuan mnghadapi situasi kerja (X4.2)

1.000

4. Nilai Eigenvalue, Persentase Varians dan Presentase Komulatif Varians dari tujuh variabel Pembentuk Motivasi faktor Karakteristik Pribadi Mahasiswa Pariwisata Bali Magang Kerja di Amerika Serikat => Kontribusi faktor pembentuk persepsi (\%) dan tingkat signifikansi akar ciri (eigenvalue)

\begin{tabular}{ccccccc}
\hline \multirow{2}{*}{ Componen } & \multicolumn{3}{c}{ Initial Eigenvalues } & \multicolumn{2}{c}{ Extraction Sums of Squared Loadings } \\
\cline { 2 - 6 } & Total & \% of Variance & Cumulative \% & Total & \% of Variance & Cumulative \% \\
\hline 1 & 1.100 & 54.996 & 54.996 & 1.100 & 54.996 & 54.996 \\
2 & .900 & 45.004 & 100.000 & & & \\
\hline
\end{tabular}

5. Matrik Motivasi faktor Karakteristik Pribadi Mahasiswa Pariwisata Bali Magang Kerja di Amerika Serikat dengan rotasi Oblimin with Kaiser Normalization => Korelasi setiap variabel terhadap faktor terbentuk

\begin{tabular}{lc}
\multicolumn{1}{c}{ Variabel } & $\begin{array}{c}\text { Componen } \\
\text { Peningkatan stamina (X4.1) }\end{array}$ \\
Kecerdasan dan kemampuan mnghadapi situasi kerja (X4.2) & .742 \\
\hline
\end{tabular}

Sumber : Hasil Analisis SPSS

Variabel kemampuan peningkatan kecerdasan mahasiswa dalam menghadapi situasi kerja digambarkan dengan kondisi sangat baik oleh mahasiswa. Dengan mengikuti kegiatan magang kerja pada stituasi kerja tertentu dalam perusahaan, mahasiswa mengetahui dan belajar bagaimana melakukan pekerjaan yang ditugaskan.

Analisis komunalitas faktor motif diperoleh hasil bahwa kemampuan ekspresi emosi memiliki nilai komunalitas 0.664, pengembangan kompetensi diri memiliki nilai komunalitas 0.610 , dan peningkatan kebutuhan psikologis memiliki nilai komunalitas 0.710. Bila dilihat dari hasil perhitungan total variance explained diperoleh hasil bahwa terdapat 1 faktor yang mampu menjelaskan variabel sebesar $66.124 \%$ dengan nilai ekstraksi untuk variabel kemampuan ekspresi emosi sebesar 0.815 , pengembangan kompetensi diri 0.781 dan peningkatan kebutuhan psikologis sebesar 0.842. Berdasarkan 
hasil analisis pada komponen matrik diperoleh hasil bahwa secara umum dapat terbentuk 1 kelompok variabel. Diantara tiga variabel motif, faktor kemampuan ekspresi emosi merupakan variabel yang memiliki nilai paling rendah dibandingkan variabel lainnya. Dalam pelaksanaan pekerjaan sesuai dengan tanggung jawab kerja, karyawan atau mahasiswa magang dituntut mampu melakukan pekerjaan sesuai dengan target perusahaan (Tabel 7).

Tabel 7. Hasil Statistik Motivasi Faktor Motif Mahasiswa Pariwisata Bali Magang Kerja di Amerika Serikat

1. Hasil Test KMO and Bartlett's Test Motivasi Faktor Motif Mahasiswa Pariwisata Bali Magang Kerja di Amerika Serikat $=>$ kebenaran pembentuk faktor

\begin{tabular}{lrr}
\hline Kaiser-Meyer-Olkin Measure of Sampling Adequacy. & .679 \\
Bartlett's Test of Sphericity & Approx. Chi-Square & 89.173 \\
& Df & 3 \\
& Sig & .000
\end{tabular}

2. Matrix Korelasi antar variabel pembentuk Motivasi Faktor Motif Mahasiswa Pariwisata Bali Magang Kerja di Amerika Serikat => korelasi faktor dengan anti image

\begin{tabular}{clccc}
\hline & & $\mathrm{X}_{4.1}$ & $\mathrm{X} 4.2$ & $\mathrm{X} 4.3$ \\
\hline \multirow{2}{*}{ Anti-image } & Kemampuan dalam mengekspresikan emosi-emosi (X5.1) & .663 & -.159 & -.273 \\
Covariance & Mengembangkan kompetensi diri (X5.2) & -.159 & .720 & -.223 \\
& Peningkatan kebutuhan psikologis (X5.3) & -.273 & -.223 & .622 \\
\hline \multirow{2}{*}{ Anti-image } & Kemampuan dalam mengekspresikan emosi-emosi (X5.1) & .677 & -.230 & -.425 \\
Corelation & Mengembangkan kompetensi diri (X5.2) & -.230 & .724 & -.333 \\
& Peningkatan kebutuhan psikologis (X5.3) & -.425 & -.333 & .649 \\
\hline
\end{tabular}

3. Komunalitas variabel faktor Motif Mahasiswa Pariwisata Bali Magang Kerja di Amerika Serikat => pengaruh (\%) setiap variabel terhadap Motivasi Mengikuti Magang

\begin{tabular}{llc}
\hline & Initial & Exstraction \\
\hline Kemampuan dalam mengekspresikan emosi-emosi (X5.1) & 1.000 & .664 \\
Mengembangkan kompetensi diri (X5.2) & 1.000 & .610 \\
Peningkatan kebutuhan psikologis (X5.3) & 1.000 & .710 \\
\hline
\end{tabular}

4. Nilai Eigenvalue, Persentase Varians dan Presentase Komulatif Varians dari tujuh variabel Pembentuk Motivasi faktor Motif Mahasiswa Pariwisata Bali Magang Kerja di Amerika Serikat => Kontribusi faktor pembentuk persepsi (\%) dan tingkat signifikansi akar ciri (eigenvalue)

\begin{tabular}{ccccccc}
\hline \multirow{2}{*}{ Componen } & \multicolumn{3}{c}{ Initial Eigenvalues } & \multicolumn{2}{c}{ Extraction Sums of Squared Loadings } \\
\cline { 2 - 6 } & Total & \% of Variance & Cumulative \% & Total & \% of Variance & Cumulative \% \\
\hline 1 & 1.984 & 66.124 & 66.124 & 1.984 & 66.124 & 66.124 \\
2 & .572 & 19.077 & 85.200 & & & \\
3 & .444 & 14.800 & 100.000 & & & \\
\hline
\end{tabular}

5. Matrik Motivasi faktor Motif Mahasiswa Pariwisata Bali Magang Kerja di Amerika Serikat dengan rotasi Oblimin with Kaiser Normalization => Korelasi setiap variabel terhadap faktor terbentuk

\begin{tabular}{lc}
\multicolumn{1}{c}{ Variabel } & $\begin{array}{c}\text { Componen } \\
\text { Faktor Motif (1) }\end{array}$ \\
\hline Kemampuan dalam mengekspresikan emosi-emosi (X5.1) & .842 \\
Mengembangkan kompetensi diri (X5.2) & .815 \\
Peningkatan kebutuhan psikologis (X5.3) & .781 \\
\hline
\end{tabular}

Sumber : Hasil Analisis SPSS

Berdasarkan hasil analisis SPSS diperoleh nilai Komunalitas yang menggambarkan sejauh mana tiap variabel memiliki pengaruh terhadap 
Tabel 8. Motivasi Faktor Mahasiswa Pariwisata Bali Magang Kerja di Amerika Serikat

\begin{tabular}{|c|c|c|}
\hline Faktor & Variabel & $\begin{array}{c}\text { Nilai } \\
\text { Komunalitas } \\
\end{array}$ \\
\hline \multicolumn{3}{|c|}{ Motivasi Ektrinsik } \\
\hline \multirow{7}{*}{$\begin{array}{l}\text { Motivasi Faktor Pengetahuan } \\
\text { Mahasiswa Mengikuti Magang } \\
\text { Kerja di Amerika Serikat }\end{array}$} & Pengaruh Bimbingan (X1.1) & 0.837 \\
\hline & Kwalitas kehidupan (X1.2) & 0.831 \\
\hline & Akibat perubahan (X1.3) & 0.608 \\
\hline & Minat mahasiswa magang (X1.4) & 0.605 \\
\hline & Kualitas dan kuantitas (X1.5) & 0.761 \\
\hline & Memberi pengalaman (X1.6) & 0.729 \\
\hline & Pembentukan karakter (X1.7) & 0.622 \\
\hline \multirow{5}{*}{$\begin{array}{l}\text { Motivasi Faktor Keterampilan } \\
\text { Mahasiswa Mengikuti Magang } \\
\text { Kerja di Amerika Serikat }\end{array}$} & Manfaat positif (X2.1) & 0.795 \\
\hline & kemampuan dalam mengelola (X2.2) & 0.770 \\
\hline & kemampuan dalam menghadapi masalah (X2.3) & 0.759 \\
\hline & Adaptasi dengan lingkungan sekitar (X2.4) & 0.746 \\
\hline & Peningkatan kemampuan (X2.5) & 0.670 \\
\hline \multirow{4}{*}{$\begin{array}{l}\text { Motivasi Faktor Konsep Diri } \\
\text { Mahasiswa Mengikuti Magang } \\
\text { Kerja di Amerika Serikat }\end{array}$} & $\begin{array}{l}\text { Peningkatan menerapakan yang di miliki oleh } \\
\text { perusahaaan }\left(\mathrm{X}_{3.1}\right)\end{array}$ & 0.819 \\
\hline & Kemampuan bertindak sismatis ( $\left.\mathrm{X}_{3.2}\right)$ & 0.796 \\
\hline & Kualitas kerja tim $\left(\mathrm{X}_{3} \cdot 3\right)$ & 0.772 \\
\hline & Tingkat ketaatan $\left(\mathrm{X}_{3} .4\right)$ & 0.672 \\
\hline \multicolumn{3}{|c|}{ Motivasi Intrinsik } \\
\hline \multirow{2}{*}{$\begin{array}{l}\text { Motivasi Faktor Karakteristik } \\
\text { Pribadi Mahasiswa Mengikuti } \\
\text { Magang Kerja di Amerika } \\
\text { Serikat }\end{array}$} & Peningkatan stamina (X4.1) & 0.742 \\
\hline & $\begin{array}{l}\text { Kecerdasan dan kemampuan mnghadapi situasi } \\
\text { kerja (X4.2) }\end{array}$ & 0.742 \\
\hline \multirow{3}{*}{$\begin{array}{l}\text { Motivasi Faktor Motif Maha- } \\
\text { siswa Mengikuti Magang Kerja } \\
\text { di Amerika Serikat }\end{array}$} & $\begin{array}{l}\text { Kemampuan dalam mengekspresikan emo- } \\
\text { si-emosi (X5.1) }\end{array}$ & 0.842 \\
\hline & Mengembangkan kompetensi diri ( $\left.\mathrm{X}_{5.2}\right)$ & 0.815 \\
\hline & Peningkatan kebutuhan psikologis $\left(\mathrm{X}_{5.3}\right)$ & 0.781 \\
\hline
\end{tabular}

Sumber : Hasil Analisis Kuisioner Desember 2015

dan ektrinsik beserta variabelnya telah mampu menggambarkan masingmasing sebesar $79.4 \%$ terhadap motivasi mahasiswa melakukan magang kerja. Sementara terdapat $20.6 \%$ faktor lain yang mempengaruhi motivasi mahasiswa melakukan magang kerja. Perhitungan analisis faktor telah menggunakan metode principal componen analysis dan metode rotasi yang digunakan adalah varimax with kaizer normalization.

\section{Penutup}

Persepsi user terhadap kualitas produktivitas mahasiswa magang kerja dipandang lebih baik dibandingkan dengan aspek kompetensi mahasiswa magang. Namun, terkait dengan variabel persepsi secara rinci oleh user adalah "kemampuan mahasiswa untuk menyelesaikan tugas dengan pengetahuan yang dimiliki” adalah buruk.

Setiap perusahaan memiliki karakteristik dan spesialisasi pekerjaan yang khas, sehingga sering kali mahasiswa magang tidak memiliki keterampilan 
atau kemampuan sesuai standar perusahaan. Mahasiswa memiliki motivasi yang sangat baik dalam hal keuntungan dengan mengikuti kegiatan magang kerja di Amerika Serikat.

Mahasiswa berpandangan bahwa kegiatan magang kerja di Amerika Serikat akan memberikan manfaat yang sangat baik dalam hal pengetahuan, keterampilan, konsep diri, karakteristik pribadi dan motif. Berdasarkan hasil analisis faktor, seluruh variabel dapat menjelaskan lima faktor yang menjadi faktor pembentuk motivasi mahasiswa untuk mengikuti magang kerja di Amerika Serikat.

Terdapat tujuh variabel dari faktor pengetahuan, lima variabel dari faktor keterampilan, empat variabel dari faktor konsep diri, dua variabel dari karakteristik pribadi dan tiga variabel dari faktor motif dapat menjelaskan motivasi dari mahasiswa untuk melakukan kegiatan magang kerja di Amerika Serikat.

Berdasarkan hasil analisis dan simpulan, disampaikan dua sarna berikut.

1. Pemberian bekal kemampuan kepada mahasiswa sebelum mengikuti magang kerja sebagai standar kemampuan yang harus dimiliki seorang pekerja pariwisata dalam menyelesaikan pekerjaannya

2. Pelaksana pendidikan kepariwisataan di Bali perlu lebih memberikan dasar pengetahuan yang lebih kepada mahasiswa khususnya terkait dengan standar kerja di sebuah negara bahkan pada suatu perusahaan sebagai user agar kegiatan magang kerja dapat memberikan manfaat positif bagi lokasi magang sebagai user dan bagi mahasiswa itu sendiri.

\section{Ucapan Terima Kasih}

Penulis mengucapkan terima kasih yang sebesar-besarnya kepada Prof. Dr. Ir. I Made Antara, MS, pembimbing utama, kepada Dr. Dewa Putu Oka Prasiasa, A.Par.,MM, Pembimbing II, kepada Rektor Universitas Udayana Prof. Dr. dr. I Ketut Suastika, Sp.PD-KEMD, kepada Direktur Program Pasasarjana Universitas Udayana yang dijabat oleh Prof. Dr.dr. A.A. Raka Sudewi, Sp.S (K), kepada Prof. Dr. I Nyoman Darma Putra, M.Litt, Ketua Program Studi Kajian Pariwisata, kepada para penguji Tesis yaitu Prof. Dr. K. G. Bendesa, M.A.D.E., Dr. Drs. I Nyoman Sunarta, M.Si., Dr. Ir. Syamsul Alam Paturusi, MSP. yang telah memberikan masukan, saran, sanggahan dan koreksi.

\section{Daftar Pustaka}

Azwar, Saifuddin. 2004. Metode Penelitian. Yogyakarta, Pustaka Pelajar.

Guerrier, Y. 1994. "Bali" dalam Baum, Tom (ed). Human Resources Issues in International Tourist. Oxford: Butterworth-Heinemman Ltd.

Hasibuan, M. 2011. Manajemen Sumber Daya Manusia. (Edisi Revisi). Jakarta: PT Bumi Aksara. 
Keputusan Menteri Tenaga Kerja dan Transmigrasi Nomor: KEP.239/MEN/X/2004 tentang Penetapan Standar Kompetensi Kerja Nasional Indonesia Sektor Pariwisata Sub Sektor Hotel dan Restoran

Mira, A. 2013."Motivasi Tenaga Kerja Bali Bekerja Di Kapal Pesiar Disney Cruise Line”. (tesis). Denpasar: Program Pascasarjana Universitas Udayana.

Palan, R. 2007. Competency Management: Teknis Mengimplementasikan Manajemen SDM Berbasis Kompetensi untuk Meningkatkan Daya Saing Organisasi. PPM. Jakarta.

Robbins, S. and Timothy A. 2008. Perilaku Organisasi. Jakarta: Salemba Empat, Edisi 12.

Sadia, K. 2011. "Motivasi Tenaga Kerja Bali bekerja Di Mediterranean Shipping Company (MSC) : Studi Kasus Di Balindo Paradiso Cruise”. (tesis). Denpasar: Program Pascasarjana Universitas Udayana.

Sunarsa, W. 2010. "Faktor-faktor Penentu Kepuasan Kerja Tenaga Kerja Bali yang Bekerja Di Kapal Pesiar: Studi Kasus di Carnival Cruise Line.” (tesis). Denpasar: Program Pascasarjana Universitas Udayana.

Witarsana, IG.A. 2012. "Pengaruh Motivasi Intrinsik dan Ekstrinsik Terhadap Kepuasan Kerja Dengan Cross Culture Adjustment Sebagai Moderating Variabel Pada Ekspatriat Hotel Bintang Lima Di Kawasan Wisata Nusa Dua."(tesis). Denpasar : Program Pascasarjana Universitas Udayana.

\section{Profil Penulis}

Putu Eka Wirawan lahir di Denpasar tanggal o5 Mei 1981 Menyelesaikan program D.IV Administrasi Perhotelan di STP Nusa Dua Bali Dengan gelar SST.Par. Saat ini penulis bekerja sebagai Dosen pada Sekolah Tinggi Pariwisata Bali Indonesia. Penulis memiliki minat penelitian terkait dengan pengembangan sumber daya manusia bidang Pariwisata dan manajemen pelayanan Perhotelan. Email : wirawanputu@ gmail.com

Prof. Dr. I Made Antara,MS adalah guru besar Fakultas Pertanian Unud, kelahiran Singaraja, 25 Desember 1954. Dia mengajar di Jurusan Sosial Ekonomi Pertanian Fakultas Pertanian (sekarang PS. Agribisnis), dan di prodi lain seperti Program Studi Magister Pariwisata, dan Program Doktor Pariwisata, Program Magister lmu Lingkungan, dan Program Doktor Kajian Budaya Universitas Udayana. Email: antara_unud@yahoo.com

Dewa Putu Oka Prasiasa adalah dosen PNS Kopertis Wilayah 8 dipekerjakan pada STIMI Handayani Denpasar dan juga Dosen Tidak Tetap Program Studi Magister Kajian Pariwisata Universitas Udayana. Oka Prasiasa menulis buku pariwisata yaitu Wacana Kontempoter Pariwisata (2011), Destinasi Pariwisata Berbasis Masyarakat (2013), dan bersama Heri Hermawan dari Pusat Penelitian dan Pengembangan Kebijakan Kepariwisataan Kementerian Pariwisata dan Ekonomi Kreatif, Oka Prasiasa mengedit buku Pengembangan Wisata Bahari di Indonesia (2012). Email: oka.dewaputu@yahoo.com 